\title{
Relationship Between Physical Activity and Stress Among Junior High School Students in the Physical Education Environment
}

\author{
David C. Barney \\ Brigham Young University, david_barney@byu.edu \\ Frank Pleban \\ Tennessee State University, fpleban@tnstate.edu \\ Terrance Lewis \\ Tennessee State University, lewisterrance1@gmail.com
}

Follow this and additional works at: https://scholarsarchive.byu.edu/facpub

Part of the Health and Physical Education Commons

\section{BYU ScholarsArchive Citation}

Barney, David C.; Pleban, Frank; and Lewis, Terrance, "Relationship Between Physical Activity and Stress Among Junior High School Students in the Physical Education Environment" (2017). Faculty Publications. 2044.

https://scholarsarchive.byu.edu/facpub/2044

This Peer-Reviewed Article is brought to you for free and open access by BYU ScholarsArchive. It has been accepted for inclusion in Faculty Publications by an authorized administrator of BYU ScholarsArchive. For more information, please contact ellen_amatangelo@byu.edu. 
Junior High PE and Stress[Type here]

Title: Relationship Between Physical Activity and Stress Among Junior High School Students in the Physical Education Environment

6

7

8

9

10

11

12

13

14

15

16

17

18

19

20

21

22

23

24

25

26

27

28

29

30

31

32

33

34

35

36

37

38

39

40

41

42

43

44

45

46 
67

68

69

70
The study purpose was to explore grade level differences $\left(7^{\text {th }}, 8^{\text {th }}\right.$, and $\left.9^{\text {th }}\right)$ among junior high school students' perception of participation in physical education class on individual environmental stress. Physical activity's role as a stress reduction tool has been well documented. However, physical activity as a stressful event in the school and physical education environment has been less established; particularly in junior high school students. Study participants were comprised of 872 junior high school students, 585 males (67\%) and 287 females $(33 \%)$, enrolled in four junior high schools. Stratified by grade, $3157^{\text {th }}$ grade students (228 males and 87 females) $(M=1.28, S D=.448), 2818^{\text {th }}$ grade students (204 males and 77 females) $(M=1.27, S D=.447)$, and $2769^{\text {th }}$ grade students $(153$ males and 123 females $)(M=$ $1.45, S D=.498)$ responded. By grade level, significant differences $(\mathrm{p}<.05)$ were reported for five of the twelve scaling questions. In general, $7^{\text {th }}$ graders were more likely to respond they could better handle stress after participating in PE class, looked forward to coming to their physical education, reported lower stress levels before arrival to PE class, and reported lower stress levels after participation in PE class, than $8^{\text {th }}$ and $9^{\text {th }}$ graders. Altogether, follow-up qualitative finding reported three major themes regarding the physical education environment and stress. Physical education acted as a stress mitigation mechanism and an opportunity for social bonding. Qualitative findings also referenced classmates as a negative stress mechanism in the physical education environment.

\section{Key Words: Stress, Physical Education, Junior High School Student}

0

1

2

3

4

5

6

7

78

79

80

0


Junior High PE and Stress[Type here]

\section{Introduction}

Every person, at some point in time and at varying degrees, experiences stress. According to Grant et al. (2003), stress has been defined as “...environmental events or chronic conditions that objectively threaten the physical and/or psychological health and well-being of individuals of a particular age in a particular society" (p. 462). Because stress is an inevitable part of life, an individual needs to be equipped with healthy mechanisms to combat stressors. Physical activity is one positive stress management method to address life stressors (Aherne, 2001; Barney, Benham, \& Haslem, 2014; Haugland, Wold, \& Torsheim, 2003).

Literature specific to the relationship between physical activity and stress has indicated that physical activity is a likely mediator between stress and health (or illness) (Gill, 1994). Physical activity has been associated with a reduced psychological stress response (Rejeski, Thompson, Brubaker, \& Miller, 1992) and decreased physiological responsiveness to physical and psycho-social stressors (Blumenthal et al., 1989; Dishman, 1994; Petonnet \& Szabo, 1993; Rimmele, 2007); resulting in psychological and physiological benefits enabling individuals to more effectively cope with stress (Fleshner, 2005; Taylor, 2000). Conversely, less active or nonactive individuals tend to experience more susceptibility to the adverse influences of life stress (Crews \& Landers, 1987), increased illness when experiencing negative life events (Brown, 1991), and slower recovery from stressful events (Crews \& Landers, 1987).

\section{Stress Response to Physical Activity in the Physical Education (PE) Environment}

Physical activity levels, through participation in sports or structured physical activities, and stress levels were investigated in a sample of Norwegian adolescents. Results indicated changes from low physical activity levels to moderate or high levels of physical activity was associated with lower levels of reported stress (Moljord, Moksnes, Ericksen, \& Espenes, 2011). 
Junior High PE and Stress[Type here]

Haugland, Wold, \& Torsheim, (2003) surveyed adolescents and compared their perceived school-related stress and leisure-time physical activity outside of school. Participants who reported school-related stress were less likely to report health complaints if they participated in leisure physical activities every week.

Research has also investigated physical activity on stress in college-aged students. Barney, Benham, \& Haslem (2014) investigated college student's perceptions regarding the effects of participation in physical activity courses on life stressors in a sample of 350 college students. Study findings suggested that a college student's participation in physical activity classes helped to mediate life stressors. Specifically, college students felt that participation in physical activity courses helped accomplishing other academic assignments. As well, this sample perceived that college student participation in physical activity helped in better handling of other life stressors.

In adolescence, physical activity can be used as the vehicle to better control personal stress. For many adolescents, common life stressors include bullying (O’Neill, 2017), family dynamics (Aherne, 2001), peer influences (Allan \& Lawless, 2003), perceived expectations of self and from others (Deutsch \& Schwertz, 2011), and difficulty in time management (Gonzalez, Hooper, Lee, \& Lin, 2010). Yet, within the school context, physical education classes provide students with opportunities to be physically active; possibly helping to mitigate daily stress. Lang et al. (2016) developed a physical education stress coping program for German speaking vocational students in Switzerland titled Effects of a Physical Education Coping Training (EPHECT). The primary purpose of EPHECT was to foster resilience through the development of an individual and adequate coping repertoire. Physical education teachers in the EPHECT program completed eight modules specific to module implementation into their regular physical 
Junior High PE and Stress[Type here]

127 education lessons. Students were instructed to perform motor leaning tasks followed by a short 128 reflection moderated by the physical education teacher. Findings suggest implementation of the

129 EPHECT program in PE classes can make positive contributions to help vocational students

130 develop adaptive coping (Puhse \& Gerber, 2005).

\section{Physical Activity as a Stressful Event in the Physical Education Environment}

Physical activity's role as a stress reduction mechanism has been well documented.

However, physical activity as a stressful event in the school and physical education environment has been less established. Little research has addressed physical education in the school environment as producing student stress; as well as ways to decrease its stressful effects (Back, 2015; Blankenship, 2013; Currie \& Sumich, 2014; Gerber, 2009; Ho, Chiang, \& Lin, 2016; Ishii \& Osaka, 2010; Lee, Kang, \& Kim, 2017). Table 1 presents systematic review findings of studies addressing student exposure to stress in the physical education environment across primary and secondary grade levels.

\section{Insert Table 1 Here}

Across all grade levels, Currie and Sumich (2014) outline several strategies in reducing stress and anxiety in physical education, in general. Positive class climate, promoting humanistic values, tolerance, individual expression, student choice, and self-evaluation are suggested for reducing PE stress. Two studies were identified addressing stress and physical education (Back, 2015; Lee, Kang, \& Kim, 2017). Back (2015) reported a negative correlation between academic stress and school physical education in high school students; with a partial mediating effect between the relationship of attitudes toward physical education and psychological well-being. 
Junior High PE and Stress[Type here]

151 Lee, Kang, \& Kim (2017) reported a correlation between high stress and athlete satisfaction and

152 burnout.

Four studies were identified addressing stress in physical education class and junior high school students (6 $6^{\text {th }}-9^{\text {th }}$ grades) (Blankenship, 2015; Gerber, 2009; Ho, Chiang, \& Lin, 2016; Ishii \& Osaka, 2010). Ho, Chiang, \& Lin (2016) identified stress in junior high physical education to athletic training and competition; with Ishii \& Osaka (2010) identifying exercise inand-of-itself as a stress-inducing agent. Additionally, Ishii and Osaka (2010) reported that junior high school students who disliked physical education and sport did not benefit from stressreducing potential of physical education. Gerber (2009), similar to Ishii and Osaka (2010) identified that stressful junior high school physical education experiences negatively impacted positive attitudes towards physical activity and PE. Junior high school physical education experiences leading to increased class stress included: issues with a teacher or classmates, psychological and physical violence, pain or discomfort, poor classroom organization and class structure, and low perceived ability or consistent feelings of failure (Gerber, 2009).

A review by Blankenship (2013) addressed several methods, similar to Currie and Sumich (2014) to reduce stress during junior high PE, including: creating developmentally appropriate tasks, private practice sessions, the use of stations, practice sessions, creating a motivational climate, and changing student perceptions of demands and abilities.

\section{Materials and Methods}

For this study the salutogenic approach conceptual framework was utilized (Quennerstedt, 2008). The salutogenic conceptual framework is not about what health is, but pays attention to resources in the creation, preservation, and development of health.

\section{Quennerstedt stated:}


Junior High PE and Stress[Type here]

Physical activity and movement can be regarded as something more than mere protection against disease or overweight, and by posing salutogenic questions we can enrich our understanding of the relation between physical activity and health, and in consequence richness to the perspective of health in physical education. (p. 277) For the purpose of this study the 'resources' was the physical education class. It is implied that physical education class can serve as a way to help students maintain and control their stress. The purpose of this study was to investigate what extent do grade level differences $\left(7^{\text {th }}, 8^{\text {th }}\right.$, and $\left.9^{\text {th }}\right)$ exist among junior high school students' perception of participation in physical education class on individual environmental stress.

\section{Participants}

For this study, 822 junior high school students (585 males and 287 females) from four intact junior high schools, three from Utah and one from California, were sampled. Student ages ranged 11 to 15 years. Grade levels for all four junior high schools encompassed of $7^{\text {th }}, 8^{\text {th }}$, and $9^{\text {th }}$ grades. Stratified by grade level, $3157^{\text {th }}$ grade students (228 males and 87 females), $2818^{\text {th }}$ grade students (204 males and 77 females), and $2769^{\text {th }}$ grade students (153 males and 123 females) responded to the survey instrument.

\section{Study Question}

1. To what extent do grade level differences exist among junior high school students' perception of participation in physical education class on individual environmental stress?

\section{Instrumentation}

Through a review of the literature, investigators did not identify an instrument specific to physical education class and stress related to junior high school students. For this study, a 12- 
Junior High PE and Stress[Type here]

197 question survey instrument was developed. The survey consisted of six questions with yes/no/sometimes response options (two of six yes/no/sometimes response questions contained qualitative follow-up), three questions with Likert scale response options (1=low; $2=$ medium; 3=high; and 4=very high) (one of the three Likert scale response questions contained qualitative follow-up), and three demographic questions. To establish content validity, junior high aged students reviewed survey questions for clarity and understanding. For reliability, the instrument was pilot-tested on junior-aged students who did not participate in this study. (questions 3-8), self-reported stress levels before and after physical education class (questions 9 and 10), and self-perception of participation in physical education for daily stress management 207 (question 11).

\section{Procedures} implementation, investigators contacted the junior high physical educators explaining both the study and survey. After securing agreement from the physical educators, the researchers had them administer the surveys to their student. Before survey administration, the physical took approximately 15 minutes. (IRB) reviewed study protocol and granted approval to conduct the study. All participants were subsequently assured that their voluntary decision to participate or not participate in the study would not affect their grade in class or class standing. A $98 \%$ survey response rate was recorded. 
Junior High PE and Stress[Type here]

The school's classes ran on block schedule, A-day/B-day with class lasting approximately 80 minutes, from bell to bell. Quantitative and qualitative data were analyzed regarding junior high school students' experiences with physical education class and individual stress. Only observed data were used for quantitative and qualitative analyses.

\section{Quantitative Research Design}

The study was quasi-experimental mixed-methods design. Data were collected in the form of survey from 872 participants (junior high school students), 585 males (67\%) and 287 females $(33 \%)$, enrolled in four junior high schools. Stratified by grade level, $3157^{\text {th }}$ grade students (228 males and 87 females) $(M=1.28, S D=.448), 2818^{\text {th }}$ grade students (204 males and 77 females $)(M=1.27, S D=.447)$, and $2769^{\text {th }}$ grade students (153 males and 123 females $)$ $(M=1.45, S D=.498)$ responded to the survey instrument.

The following survey questioners were considered for analyses:

1. "When I come to this physical education class, I forget about what is stressing me out?" (question 3)

2. "After participating in the class activities, I feel I can handle what is stressing me out?" (question 5)

3. "I look forward to coming to my physical education class?" (question 6)

4. "Rate your stress when you arrive to your physical education class." (question 9)

5. "Rate your stress after you have finished participation in your physical education class." (question 10)

The response choices given for question 6 were: Yes, No, or Sometimes. The Likert scaling response choices given for questions 9 and 10 were: (1=low; 2=medium; 3=high; and 4=very high)

\section{Quantitative Data Analysis}

Analyses were performed on student response data to the survey instrument. Quantitative data analysis consisted of a Pearson's Chi-Squared Tests $\left(\chi^{2}\right)$; as well as measures of central tendency and dispersion. Chi-Square Tests were conducted used to compare stress in the physical 
Junior High PE and Stress[Type here]

248

249

250

251

252

253

254

255

256

257

258

259

260

261

262

263

264

265

266

267

268

269

270

education environment stratified by grade level and significant effects reported. Chi-Squares, levels of significance $(p<.05)$ were reported for all significant effects. SPSS Statistics 21 was used for analyses. Only observed data values were used for these summaries. Significant differences were reported for three (questions $3,5,6,9$, and 10) of the nine scaling questions when compared to grade level.

A Chi-Square Tests showed that there was a statistically significant difference by grade level in questions related to physical education and stress between grade levels. Question 3 "When I come to this physical education class, I forget about what is stressing me out?" indicated an association by grade level, with $7^{\text {th }}$ graders $(M=1.70, S D=.877), 8^{\text {th }}$ graders $(M=$ $1.96, S D=.782)$, and $9^{\text {th }}$ graders $(M=2.02, S D=.903) ; \chi^{2}(4, N=872)=12.53, p<.01$. Cramer's V effect size was .085, representing a small effect. Students in $7^{\text {th }}$ grade were more likely to forget about stress $(37.1 \%)$, than $8^{\text {th }}(36.5 \%)$ and $9^{\text {th }}(26.4 \%)$ grade students when coming to PE class. (Figure 1) Question 5 "After participating in the class activities, I feel I can handle what is stressing me out?" indicated an association by grade level, with $7^{\text {th }}$ graders $(M=$ $1.66, S D=.856), 8^{\text {th }}$ graders $(M=1.92, S D=.772)$, and $9^{\text {th }}$ graders $(M=2.16, S D=.906) ; \chi^{2}(4$, $N=872)=17.41, p<.01$. Cramer's V effect size was .100, representing a small effect. Students in $7^{\text {th }}$ grade were more likely to respond that they could better handle stress $(41.7 \%)$, than $8^{\text {th }}$ $(31.5 \%)$ and $9^{\text {th }}(26.9 \%)$ grade students after participating in PE class. (Figure 2) For question 6 "I look forward to coming to my physical education class?" indicated an association by grade level, with $7^{\text {th }}$ graders $(M=1.50, S D=.838), 8^{\text {th }}$ graders $(M=1.40, S D=.805)$, and $9^{\text {th }}$ graders $(M=1.78, S D=.940) ; \chi 2(4, N=872)=25.23, p<.0001$. Cramer's V effect size was .120 , representing a small effect. Students in $7^{\text {th }}$ grade were more likely to look forward to coming to their physical education class (38.0\%), than $8^{\text {th }}(36.5 \%)$ and $9^{\text {th }}$ (26.4\%). (Figure 3) For question 
Junior High PE and Stress[Type here]

9 "Rate your stress when you arrive to your physical education class." indicated an association by grade level, with $7^{\text {th }}$ graders $(M=1.68, S D=.798), 8^{\text {th }}$ graders $(M=1.69, S D=.798)$, and $9^{\text {th }}$ graders $(M=1.93, S D=.959) ; \chi^{2}(4, N=872)=23.54, p<.001$. Cramer's V effect size was .116 , representing a small effect. Students in $7^{\text {th }}$ reported lower stress levels before arrival to PE class $(38.8 \%)$, than $8^{\text {th }}(33.3 \%)$ and $9^{\text {th }}(27.9 \%)$. (Figure 4$)$ For question 10 "Rate your stress after you have finished participation in your physical education class." indicated an association by grade level, with $7^{\text {th }}$ graders $(M=1.45, S D=.766), 8^{\text {th }}$ graders $(M=1.47, S D=.820)$, and $9^{\text {th }}$ graders $(M=1.71, S D=.911) ; \chi^{2}(4, N=872)=21.04, p<.01$. Cramer's V effect size was .110 , representing a small effect. Students in $7^{\text {th }}$ grade also reported lower stress levels after participation in PE class $(38.7 \%)$, than $8^{\text {th }}(34.8 \%)$ and $9^{\text {th }}(26.5 \%)$. (Figure 5)

Insert Table 2 Here

Insert Figure 1 Here

Insert Figure 2 Here

Insert Figure 3 Here

Insert Figure 4 Here 


\section{Insert Figure 5 Here}

\section{Qualitative Follow-Up Data Analysis}

Additional data results were comprised of short-answer responses from the study participants. Thematic analysis and findings reported for 4 of the 12 survey questions (questions 4, 7, 8, and 11). Participants were asked to explain and expound their responses to the four openended questions. Thematic content analysis performed on open-ended responses. Referencing qualitative analysis, researchers read and re-read content until common themes became evident for each survey question. Responses were first examined using inductive content analysis (Lincoln \& Guba, 1985 \& Sarvela \& McDermott, 1983) in order to identify emerging themes. A constant comparative method (Glasser and Strauss, 1967) was employed, first to categorize then compare and contrast each unit of information with all other units of information with the intent of linking those with similar meanings (Patton, 2002).

Participants answered questions regarding stress indices: stress after completion of physical education class (question 4), stress reduction after participation in physical education class (question 7), stress from participation in physical education class (question 8), and participation in physical education class in managing life stressors (question 11). Analysis revealed three major themes: (a) stress mitigation from physical education, (b) social bonding from physical educatioin, and (c) PE classmates as negative stress in physical education. (Figure 6)

Insert Figure 6 Here 
Junior High PE and Stress[Type here]

\section{Stress Mitigation After Participation in the Physical Education Environment.}

Participant responses focused on the mitigation of stress after participating in physical education: "Sometimes I forget about my stress, often doing fun things in PE.", "Yes, because I think physical activity is healthy and when I run or do physical activities, it helps get my mind off things and is like therapy.", "When I have fun I forget about the things that stress me.", "Running makes me calm.”, and, “After working out, my brain is empty and refreshed and ready for the next class."

\section{Social Bonding as Stress Reduction in the Physical Education Environment.}

Referencing social bonding as a stress reducer, responses included: "Because I can talk to friends, and physical activity can help me forget about stress.", "I get to hang out with my friends and talk to them about life.", and "I talk to my friends and play sports."

One minor theme that arose from was, for stress reduction during class, stress reduction in PE was contingent on activity type. Statements included: "If I enjoy the activity and get into what's happening during PE, it occasionally takes my mind off of my stress.", and "Depends on what we do in PE class."

Classmates as Negative Stress in the Physical Education Environment. Conversely, to the major theme of social bonding, participant responses focused on classmates as producing stress in the physical education environment: "Classmates are too much.”, "I don't like some kids in my class.", and concise responses such as "Bullies!"

\section{Discussion}

The purpose of this study was to explore grade level differences (7th, 8th, and 9th) among junior high school students' perception of participation in physical education class on individual environmental stress. Findings suggest PE class helped junior high school students 
Junior High PE and Stress[Type here]

350 with stress in their lives, particularly among $7^{\text {th }}$ grade students. In general, $7^{\text {th }}$ graders were more 351 likely to respond they could better handle stress after participating in PE class, looked forward to 352 coming to their physical education, reported lower stress levels before arrival to PE class, and 353 reported lower stress levels after participation in PE class, than $8^{\text {th }}$ and $9^{\text {th }}$ graders. Overall, 354 follow-up qualitative findings also helps support quantitative results. For reference, when 355 students left PE class they felt their participation in class activities helped them "be more calm", 356 "distracted me from my worries" and helped get "their mind off things." Moljord et al. (2011) 357 studied the relations of physical activity, stress, and happiness in a sample of Norwegian 358 360 beneficial mechanism for adolescents to address stress. adolescents, 13 to 18 years old. Moljord et al. (2011) reported adolescents with moderate or high physical activity levels reported lower stress and higher happiness than adolescents with lower physical activity levels.

Another point of discussion references participants expressing their feelings and thoughts in regards to PE class helping them lessen stress experienced from daily stress. Sharp and Barney (2016) studied the effects of stress in college students attending a university that did not require physical activity classes for graduation compared to students attending a university requiring students to take physical activity classes for graduation. Students participating in physical activity classes recorded the following statements, "I still have stress, but physical activity helps", "I would be more cranky and restless without it", "I feel I am in a better mood and can handle situations better", and "It relieves my stress and problems so I can encounter them." Finds parallel with previous research, while adding to the literature supporting one potential

One of the main goals of physical education is to make activities and games fun and enjoyable (NASPE, 2009). Yet, historically physical educators have used inappropriate 
Junior High PE and Stress[Type here]

373 instructional practices in activities and games that have not been fun and enjoyable for students.

374 Thus, possibly creating or adding stress for the student. Barney, Pleban, Fullmer, Griffiths,

375 Higginson, \& Whaley (2016) studied exercise as punishment in physical education class and its

376 effects on former students' attitudes. Participants were interviewed about their past PE

377 experiences and the use of exercise as punishment. Participants were asked, "Was the overall

378 classroom environment affected when students had to exercise as punishment?" Overwhelming,

379 participants reported "yes", the classroom environment was negatively affected. Additional

380 statements included, "The atmosphere usually became tense", "It's awkward to watch", "It

381 scares the group or makes them feel uneasy", and "It made us fear the teacher." Student

382 responses do not specifically address stress from exercise and punishment, yet the responses

383 alluded to the notion that these experiences did not create a positive learning environment.

\section{Implications for Physical Education Teacher Education Programs}

The salutogenic conceptual framework states, "understanding of the relation between physical activity and health and in consequence richness to the perspectives of health in physical education" (Quennerstedt, 2008). After data and thematic content analyses, junior high school students participating in PE class tend to report better stress management. Another implication from this study is that PE teachers should be mindful of activities students can participate in that will be most beneficial in helping students relieve stress in their lives. Table 2 outlines Physical student stress in the physical education environment. 
Junior High PE and Stress[Type here]

Additionally, Pangrazi and Beighle (2013) suggested when students enter class they should be engaged in activity; with active teacher interaction.

One last implication of this study that Physical Education Teacher Education (PETE) faculty should be mindful of their preparing PETE majors and that benefits that can come to their students through participation in class activities thus resulting in managing stress in their lives. When the PETE major graduates and teaches their own classes, they can use this information to better inform parents, administrators, and the classroom teachers the benefits of student's activity in PE class and throughout the student's life.

\section{Study Limitations}

Investigators have noted certain limitations to this study. Four junior high schools from two states participated in this study. The four junior high schools in this study were from two states. Because the participants came from certain locales and grade levels, it may not allow a representative sampling of participants from other schools, grade levels, or in other geographic regions, thus limiting the generalizing of the findings. Thus, themes, conclusions, and implications are mostly applicable to those participant demographics. Research on refining physical education teacher education and the physical education environment needs to be continued in new meaningful directions. Physical education teacher education research should continue incorporate diverse investigation methodology in order to better examine the environmental factors in the physical education environment (Hassandra, Goudas, \& Chroni, 2003). In order to identify more robust causal relationships between stress and physical activity, a longitudinal study design would be needed. 
Junior High PE and Stress[Type here]

\section{References}

Aherne, D. (2001). Understanding stress: A qualitative approach. Irish Journal of Psychology, 22,176-187.

Allan, J., \& Lawless, N. (2003). Stress caused by on-line collaboration in E-learning: A developing model. Education and Training, 45, 564-572.

Barney, D., Benham, L., \& Haslem, L. (2014). Effects of college student's participation in physical activity classes on stress. American Journal of Health Studies, 29, 155-160.

Barney, D., Pleban, F., Fullmer, M., Griffiths, R., Higginson, K., \& Whaley, D. (2016). Apropriate or inappropriate practice: Exercise as punishment in physical education class. The Physical Educator, 73, 59-73.

Back, K. (2015). The Mediating Effects of Hope between Attitude toward School Physical Education, Academic Stress, Ego-Resilience, and Psychological Wellbeing of High School Students. Indian Journal Of Science And Technology, 8(S7), 596-602. doi:10.17485/ijst/2015/v8iS7/70446

Blankenship, B. (2013). The stress process in physical education. Journal of Physical Education, Recreation, and Dance, 78(6), 39-44.

Blumenthal, J.A., Fredrikson, M., Kuhn, C.M., Ulmer, R.L., Walsh-Riddle, M., \& Applebaum, M. (1989). Aerobic exercise reduces levels of cardiovascular and sympathoadrenal responses to mental stress in subjects without prior evidence of myocardial ischemia. American Journal of Cardiology, 65, 93-98.

Brown, J.D. (1991). Staying fit and staying well: Physical fitness as moderator of life stress. Journal of Personality and Social Psychology, 60, 555-561. 
Junior High PE and Stress[Type here]

444 Crews, D.J., \& Landers, D.M. (1987). A meta-analytic review of aerobic fitness and

445

446

447

448

449

450

451

452

453

454

455

456

457

458

459

460

461

462

463

464

465

466 reactivity to psychosocial stressors. Medicine ans Science in Sports and Exercise, 19, S114-S120.

Currie, J. L. \& Sumich, K. (2014). Creating stress-free learning environments for sport and physical education. Journal of Sports Pedagogy and Physical Education, 5(1), 15-21. doi:10.18848/2381-7100/CGP/v05i01/59426.

Deutsch, M.L., \& Schmertz, B. (2011). “Starting from ground zero”: Constraints and experiences of adult women returning to college. The Review of Higher Education, 34, 477-504

Dishman, R. (1994). Biological psychology, exercise, and stress. Quest, 46, 28-59.

Fleshner, F. (2005). Physical activity and stress resistance: Sympathetic nervous system adaptations prevent stress-induced immunosuppression. Exercise \& Sport Sciences Review, 33, 120-126.

Gerber, M. (2009). Changes in satisfaction with physical education and Intrinsic sport motivation as a function of chronic stress experiences in physical education classes. In T. F. Cuddihy \& E. Brymer (Eds.), Creating active futures: Edited Proceedings of the $26^{\text {th }}$ (pp. 311318). School of Human Movement Studies: Queensland University of Technology.

Gill, D.L. (19940. A sport and exercise psychology perspective on stress. Quest, 46, 2027.

Glasser, B.G., \& Strauss, A.L. (1967). The Discovery of Grounded Theory. New York, NY: Aldine. 
Junior High PE and Stress[Type here]

467

468

469

470

471

472

473

474

475

476

477

478

479

480

481

482

483

484

485

486

487

488

489

Gonzalez, T., Hooper, H.H., Lee, A.S., \& Lin, J. (2010). A study of correlations among yoga enhancement design and cognition of college student learning and practitioner success. International Journal of Organizational Innovation, 2, 271-286.

Grant, K.E., Compas, B.E., Stuhlmacher, A.F., Thurm, A.E., McMahon, S.D., \& Halpert, J.A. (2003). Stressors and child and adolescent psychopathology: Moving from markers to mechanism of risk. Psychological Bulletin, 129,447-466.

Hassandra, M., Goudas, M., \& Chroni, S. (2003). Examining factors associated with intrinsic motivation in physical education: A qualitative approach. Psychology of Sport and Exercise, 4, 211-223.

Haugland, S., Wold, B., \& Torsheim, T. (2003). Relieving the Pressure? The role of physical activity in the relationship between school-related stress and adolescent health complaints. Research Quarterly for Exercise and Sport, 74, 127-135.

Lee, K., Kang, S., \& Kim, I. (2017). Relationships among stress, burnout, athletic identity, and athlete satisfaction in students at Korea's physical education high schools: Validating differences between pathways according to ego resilience. Psychological Reports, 120(4), 585-608.

Li-Hsing Ho, L-H., Chiang, Y-T., \& Lin, T-H. (2016). A study on relation between stress and coping strategies of junior high school students in the physical education programs. International Journal of Economics and Research, 7(6), 121-128.

Ishii, N. \& Osaka, S. (2010). Physical Education and the Degree of Stress. Journal of Human Kinetics, 24, pp. 87-92. Retrieved 12 Dec. 2017, from doi:10.2478/v10078-010-0024-3 
Junior High PE and Stress[Type here]

Lang, C., Feldmeth, A.K., Brand, S., Trachsler, E.H., Puhse, U., \& Gerber, M. (2016). Stress management in physical education class: An experiential approach to improve coping skills and reduce stress perceptions in adolescents. Journal of Teaching in Physical Education, 35, 149-158.

Lincoln, Y.S., \& Guba, E.G. (1985). Naturalistic Inquiry (pp.339-344). Newbury Park: Sage.

Moljord, I.E.O., Moksnes, U.K., Ericksen, L., \& Espnes, G.A. (2011). Stress and happiness among adolescents with varying frequency of physical activity. Perceptual and Motor Skills, 113, 631-646.

National Association for Sport and Physical Education. (2009). Appropriate instructional practice guidlelines for middle school physical education. Reston, VA: Author.

O’Neill, J.M. (2017, July 14). America sees alarming spike in middle school suicide rate. USA Today, 1-2.

Pangrazi, R.P., \& Beighle, A. (2013). Dynamic physical education for elementary school children ( $17^{\text {th }}$ ed.). San Francisco, CA: Benjamin Cummings.

Patton, M. Q. (2002). Qualitative research and evaluation methods. Thousand Oaks, Calif: Sage Publications.

Peronnet, F., \& Szabo, A. (1993). Sympathetic response to acute psychosocial stressors in humans: Linkage to physical exercise and training. New York, NY: Wiley.

Puhse, U., \& Gerber, M. (2005). International comparison of physical education. Aachen: Meyer \& Meyer.

Quennerstedt, M. (2008). Exploring the relation between physical activity and health-a salutogenic approach to physical education. Sport, Education and Society, 13, 267-283. 
Junior High PE and Stress[Type here]

513 Rejeski, W.J., Thompson, A., Brubaker, P.H., \& Miller, H.S. (1992). Acute exercise:

514 Buffering psychosocial stress response in women. Health Psychology, 11, 355-362.

515 Rimmele, U. (2007). Physical activity and psychosocial stress. Zurich. Cuvillier Verlag.

516 Sarvela, P.D., \& McDermott, R.J. (1993). Health Education Evaluation and Measurement: A

517 Practitioner's Perspective. Madison, WI: WCB Brown \& Benchmark.

518 Sharp, E., \& Barney, D. (2016). Required and non-required college physical activity classes effects on college students' stress. American Journal of Health Studies, 31, 74-81.

520 Taylor, A.H. (2000). Physical activity and psychological well-being. London. Routledge. 
Junior High PE and Stress[Type here] 
Junior High PE and Stress[Type here]

Table 1

Student exposure to stress in the physical education environment across primary and secondary grade levels

\begin{tabular}{|c|c|c|c|c|c|c|c|c|}
\hline Title & Author(s) & $\begin{array}{l}\text { Publication } \\
\text { Date }\end{array}$ & $\begin{array}{l}\text { Study } \\
\text { Country }\end{array}$ & $\begin{array}{l}\text { Study } \\
\text { Design }\end{array}$ & $\begin{array}{c}\text { Grade } \\
\text { Level/Age }\end{array}$ & $\begin{array}{l}\text { Sample } \\
\text { Size }\end{array}$ & $\begin{array}{l}\text { Assessment } \\
\text { Method }\end{array}$ & Outcome(s) \\
\hline $\begin{array}{l}\text { Changes in Satisfaction with } \\
\text { Physical Education and } \\
\text { Intrinsic Sport Motivation as a } \\
\text { Function of Chronic Stress } \\
\text { Experiences in Physical } \\
\text { Education Classes }\end{array}$ & Gerber & 2009 & Switzerland & $\begin{array}{l}\text { Cross- } \\
\text { sectional }\end{array}$ & $\begin{array}{l}\text { Junior High } \\
\left(6^{\text {th }} \text { to } 9^{\text {th }}\right. \\
\text { grade })\end{array}$ & $\begin{array}{l}302 \text { boys } \\
\& \text { girls }\end{array}$ & Survey & $\begin{array}{l}\text { 1. Stress negatively affected } \\
\text { intrinsic motivation \& } \\
\text { contributed to reduced PE } \\
\text { satisfaction levels. } \\
\text { 2. Stressful experiences in PE } \\
\text { impacted positive attitudes } \\
\text { towards physical activity } \\
\text { \& PE: } \\
\text { - problems with teacher or } \\
\text { classmates } \\
\text { - psychological \& physical } \\
\text { violence } \\
\text { - pain during or after PE } \\
\text { - poor organization \& class } \\
\text { - structure } \\
\text { low perceived ability or } \\
\text { consistent feelings of } \\
\text { failure. }\end{array}$ \\
\hline $\begin{array}{l}\text { Physical Education and the } \\
\text { Degree of Stress }\end{array}$ & Ishii \& Osaka & 2010 & Japan & $\begin{array}{l}\text { Cross- } \\
\text { sectional }\end{array}$ & Junior High & $\begin{array}{c}268 \\
(129 \\
\text { boys, } 139 \\
\text { girls) }\end{array}$ & Survey & $\begin{array}{l}\text { 1. Students who disliked } \\
\text { physical education \& } \\
\text { sports did not benefit from } \\
\text { stress-reducing potential of } \\
\text { exercise \& sport. } \\
\text { 2. Exercise may be stress- } \\
\text { inducing agent. }\end{array}$ \\
\hline $\begin{array}{l}\text { The Stress Process in Physical } \\
\text { Education }\end{array}$ & Blankenship & 2013 & USA & Review & $7^{\text {th }}$ grade & N/A & N/A & $\begin{array}{l}\text { 1. Reducing stress during PE: } \\
\text { - Create developmentally } \\
\text { appropriate tasks } \\
\text { - Arrange private practice } \\
\text { sessions } \\
\text { - Use stations } \\
\text { - Maximize practice } \\
\text { - Create a task-involved } \\
\text { motivational climate } \\
\text { - Identify students with } \\
\text { low perceived } \\
\text { competence/high trait } \\
\text { anxiety }\end{array}$ \\
\hline
\end{tabular}




\begin{tabular}{|c|c|c|c|c|c|c|c|c|}
\hline & & & & & & & & $\begin{array}{ll}- & \text { Change student } \\
\text { perceptions of demands } \\
\text { \& abilities } \\
\text { - Teach relaxation } \\
\text { techniques. } \\
\end{array}$ \\
\hline $\begin{array}{l}\text { Creating Stress-Free Learning } \\
\text { Environments for Sport and } \\
\text { Physical Education }\end{array}$ & $\begin{array}{c}\text { Currie \& } \\
\text { Sumich }\end{array}$ & 2014 & Australia & Review & $\begin{array}{l}\text { All Grades / } \\
\text { Non } \\
\text { Identified }\end{array}$ & N/A & N/A & 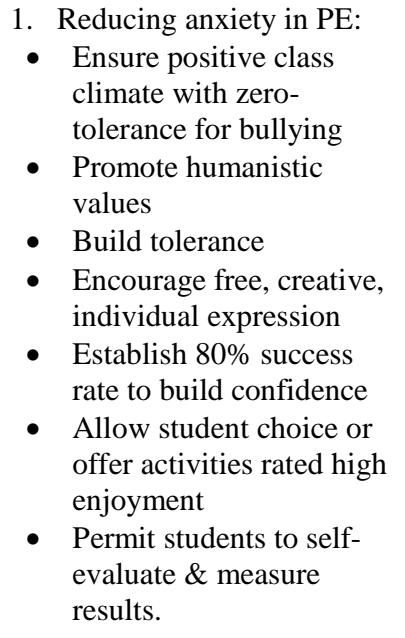 \\
\hline $\begin{array}{l}\text { The Mediating Effects of Hope } \\
\text { Between Attitude Toward } \\
\text { School Physical Education, } \\
\text { Academic Stress, Ego- } \\
\text { Resilience, and Psychological } \\
\text { Wellbeing of High School } \\
\text { Students }\end{array}$ & Back & 2015 & Korea & $\begin{array}{l}\text { Cross- } \\
\text { sectional }\end{array}$ & $\begin{array}{l}\text { High School } \\
\text { (ages } \\
14 \text { to } 18 \\
\text { years) }\end{array}$ & $780 *$ & Survey & $\begin{array}{l}\text { 1. Positive correlation toward } \\
\text { school PE: attitude toward } \\
\text { school physical education, } \\
\text { academic stress, ego- } \\
\text { resilience, \& psychological } \\
\text { well-being. } \\
\text { 2. Negative correlation } \\
\text { toward school PE: } \\
\text { academic stress. } \\
\text { 3. A partial mediating effect } \\
\text { between youth attitude } \\
\text { toward school PE \& } \\
\text { academic stress, ego- } \\
\text { resilience, \& psychological } \\
\text { well-being. }\end{array}$ \\
\hline $\begin{array}{l}\text { A Study on Relation Between } \\
\text { Stress and Coping Strategies of } \\
\text { Junior High School Students in } \\
\text { the Physical Education } \\
\text { Programs }\end{array}$ & $\begin{array}{c}\text { Ho, Chiang, \& } \\
\text { Lin }\end{array}$ & 2016 & Taiwan & $\begin{array}{l}\text { Cross- } \\
\text { sectional }\end{array}$ & Junior High & $\begin{array}{c}589 \text { boys } \\
\& \text { girls }\end{array}$ & Survey & $\begin{array}{l}\text { 1. Junior high student stress } \\
\text { in PE related to PE athletic } \\
\text { training \& competition. } \\
\text { 2. Significant differences in } \\
\text { gender, grade, competition } \\
\text { level, sports, \& experience }\end{array}$ \\
\hline
\end{tabular}


Junior High PE and Stress[Type here]

\begin{tabular}{|c|c|c|c|c|c|c|c|c|}
\hline & & & & & & & & $\begin{array}{l}\text { been in physical education } \\
\text { programs. Positive } \\
\text { correlation between stress } \\
\text { identification \& } \\
\text { application of coping } \\
\text { strategy. }\end{array}$ \\
\hline $\begin{array}{l}\text { Relationships Among Stress, } \\
\text { Burnout, Athletic Identity, and } \\
\text { Athlete Satisfaction in Students } \\
\text { at Korea's Physical Education } \\
\text { High Schools: Validating } \\
\text { Differences Between Pathways } \\
\text { According to Ego Resilience }\end{array}$ & $\begin{array}{c}\text { Lee, Kang, \& } \\
\text { Kim }\end{array}$ & 2017 & Korea & $\begin{array}{c}\text { Cross- } \\
\text { sectional }\end{array}$ & High School & $\begin{array}{c}332(225 \\
\text { boys \& } \\
107 \text { girls })\end{array}$ & survey & $\begin{array}{l}\text { 1. High stress correlated with } \\
\text { burnout \& high levels of } \\
\text { burnout negatively related } \\
\text { to athletic identity \& } \\
\text { athlete satisfaction. }\end{array}$ \\
\hline
\end{tabular}

Note N/A = Not Applicable.

*Gender not identified. 
Junior High PE and Stress[Type here]

Table 2

Physical Education Teacher Education Program Guidelines Impacting Stress in the Physical Education Environment

\begin{tabular}{|c|c|}
\hline Stress Promoting Experiences in Physical Education & Stress Mitigating Experiences in Physical Education \\
\hline $\begin{array}{l}\text { - } \quad \text { Problems with teacher or classmates. } \\
\text { - } \quad \text { Psychological \& physical violence. } \\
\text { - } \quad \text { Pain during or after PE. } \\
\text { - } \quad \text { Poor organization \& class structure. } \\
\text { - } \quad \text { Low perceived ability or consistent feelings of failure. } \\
\text { (Gerber, 2009) }\end{array}$ & $\begin{array}{l}\text { - } \quad \text { Create developmentally appropriate tasks. } \\
\text { - } \quad \text { Arrange private \& maximize practice sessions. } \\
\text { - } \quad \text { Create a task-involved motivational climate. } \\
\text { - } \quad \text { Encourage free, creative, individual expression } \\
\text { - } \quad \text { for bullying. } \\
\text { - } \text { Identify students with low perceived } \\
\text { - } \quad \text { Establish } 80 \% \text { success rate to build confidence. } \\
\text { - } \quad \text { enjoyment } \\
\text { - } \quad \text { Permit studentents to self-evaluate \& measure results. } \\
\text { - Teach relaxation techniques. } \\
\text { 1. } \quad \text { Promote humanistic values. } \\
\text { Build tolerance. (Blankenship, 2013; Currie \& } \\
\text { Sumich, 2014) }\end{array}$ \\
\hline
\end{tabular}


Figure 1. Response Rates by Grade Level for Question 3

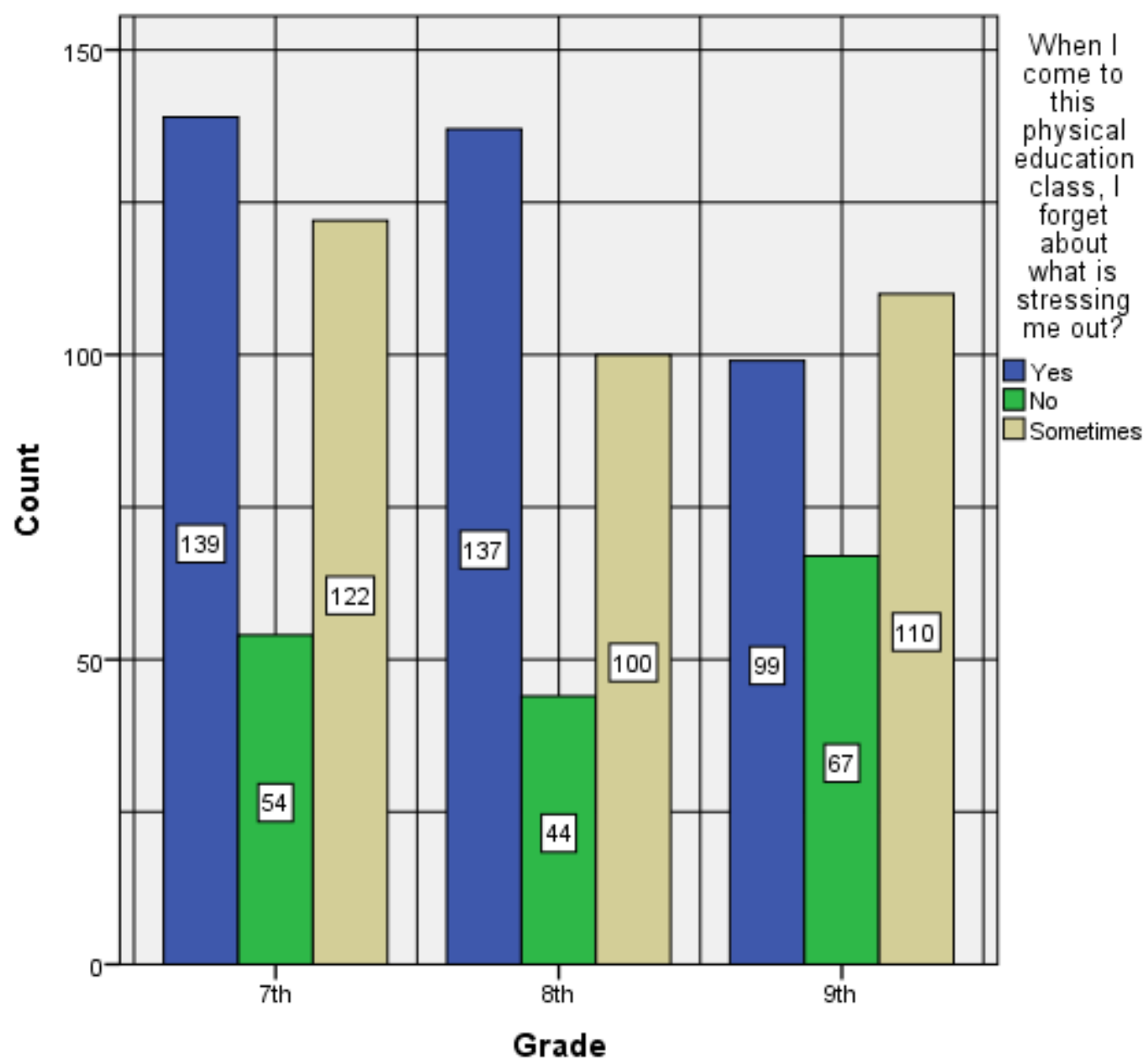


Figure 2. Response Rates by Grade Level for Question 5

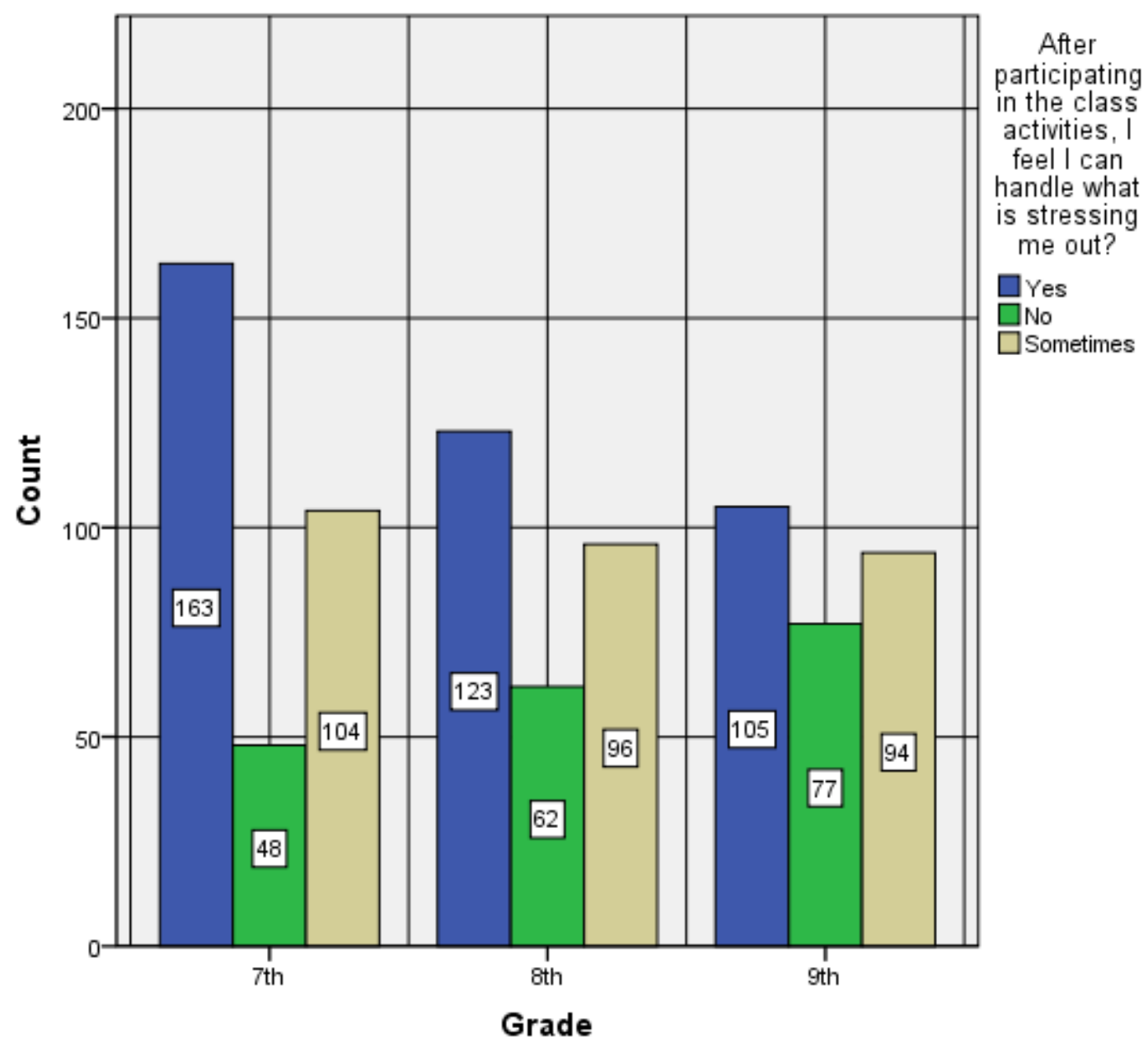


Figure 3. Response Rates by Grade Level for Question 6

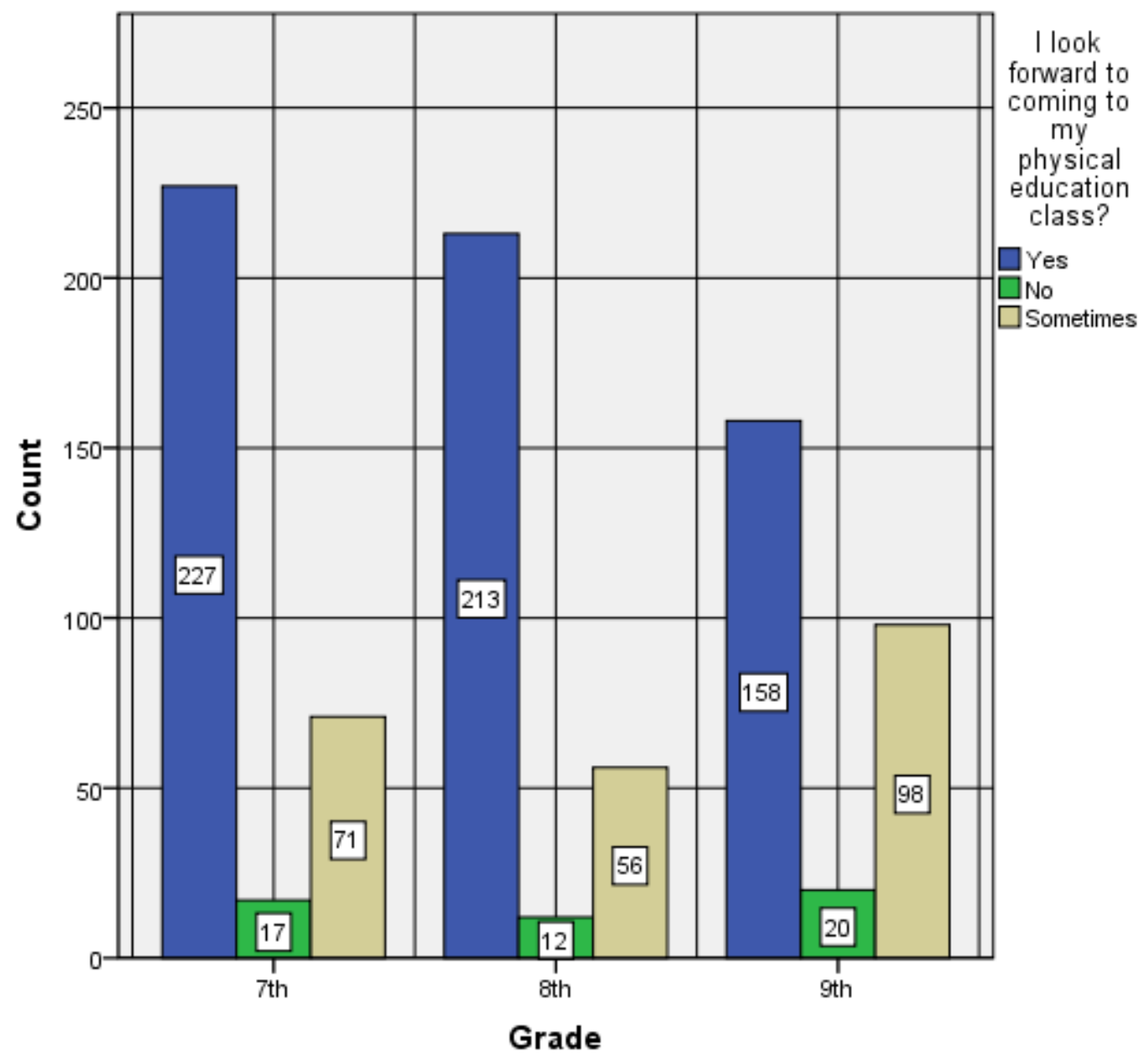


Figure 4. Response Rates by Grade Level for Question 9

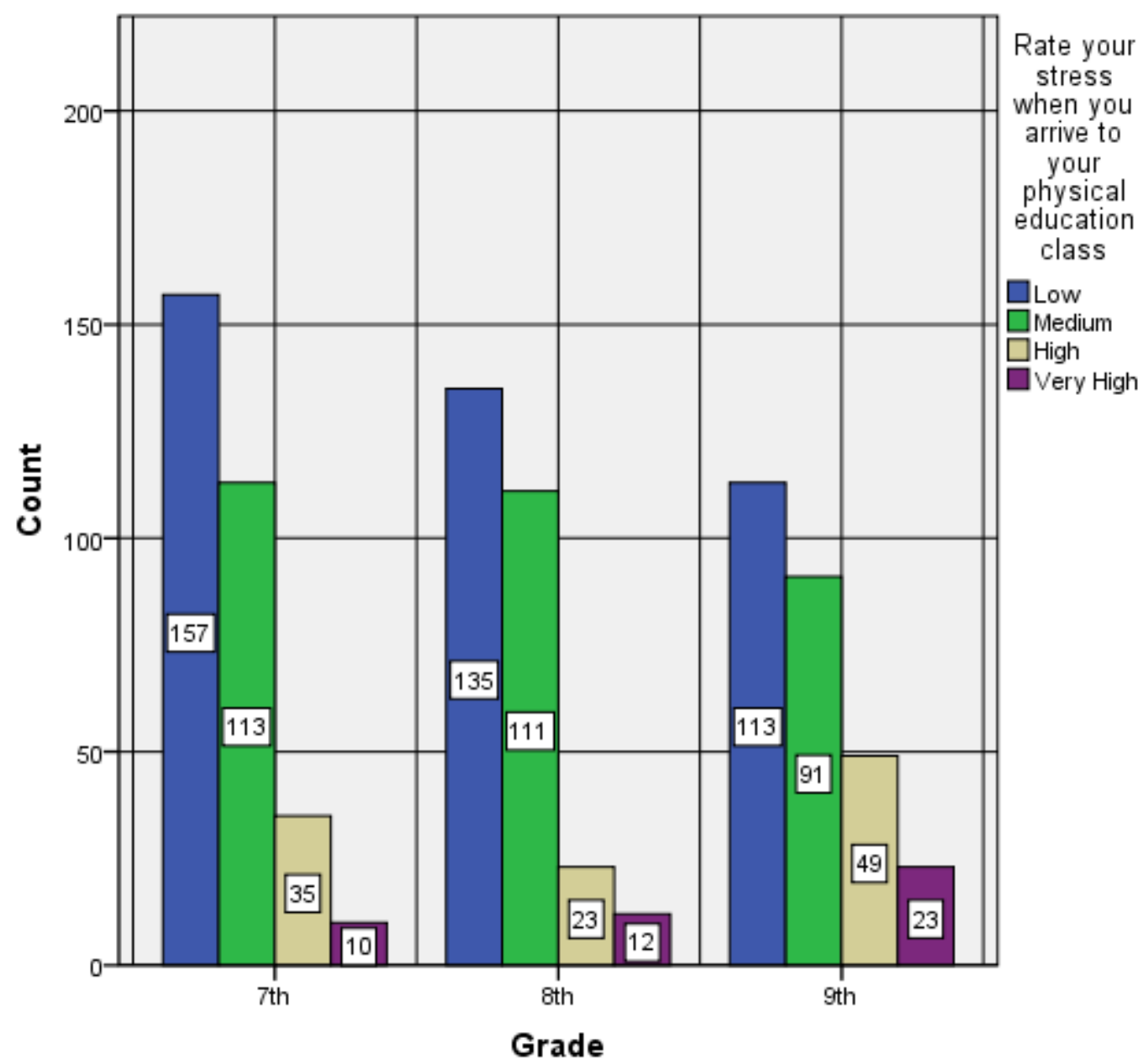


Figure 5. Response Rates by Grade Level for Question 10

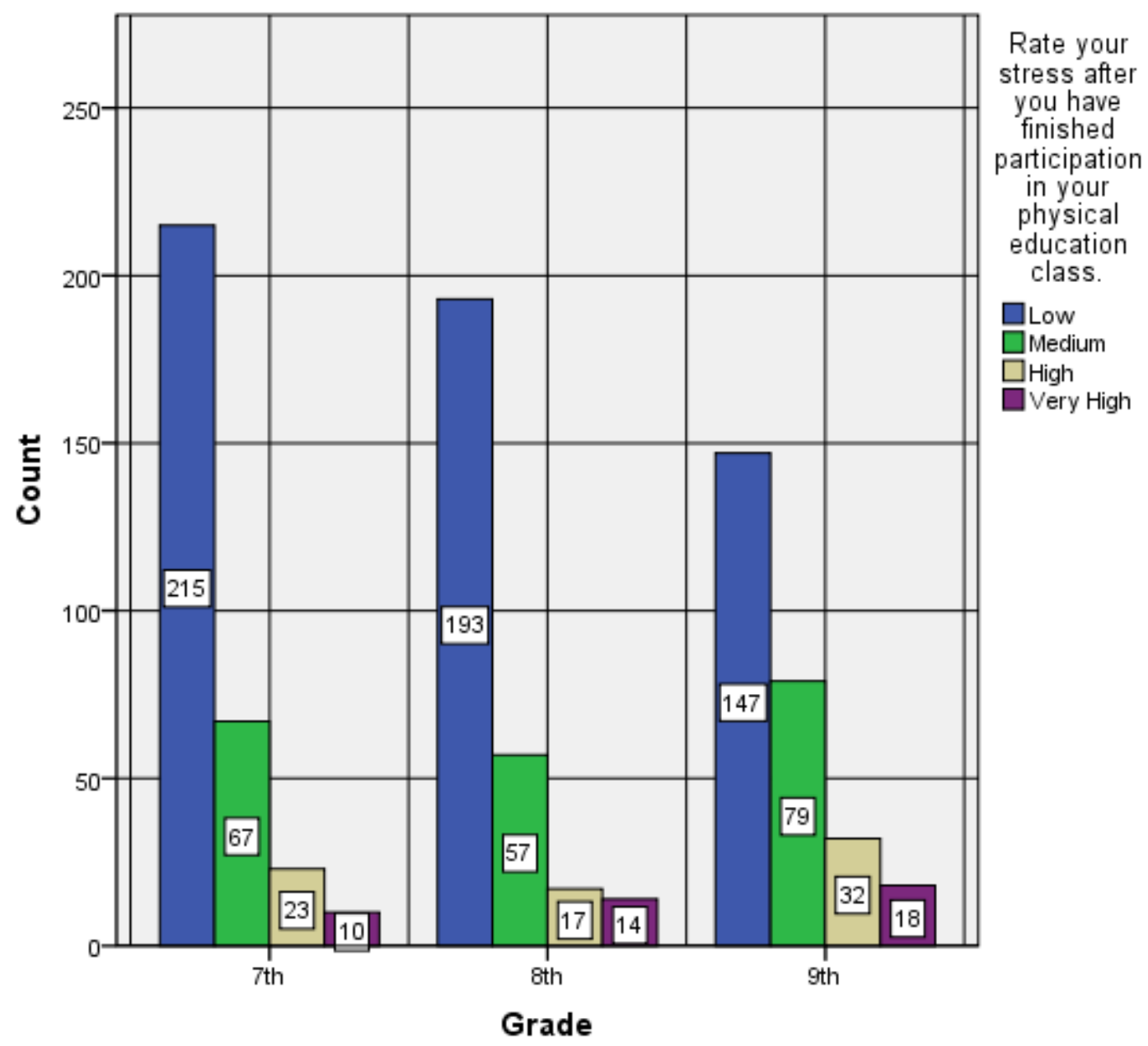


Figure 6. Stress in Physical Education: Major and Minor Themes

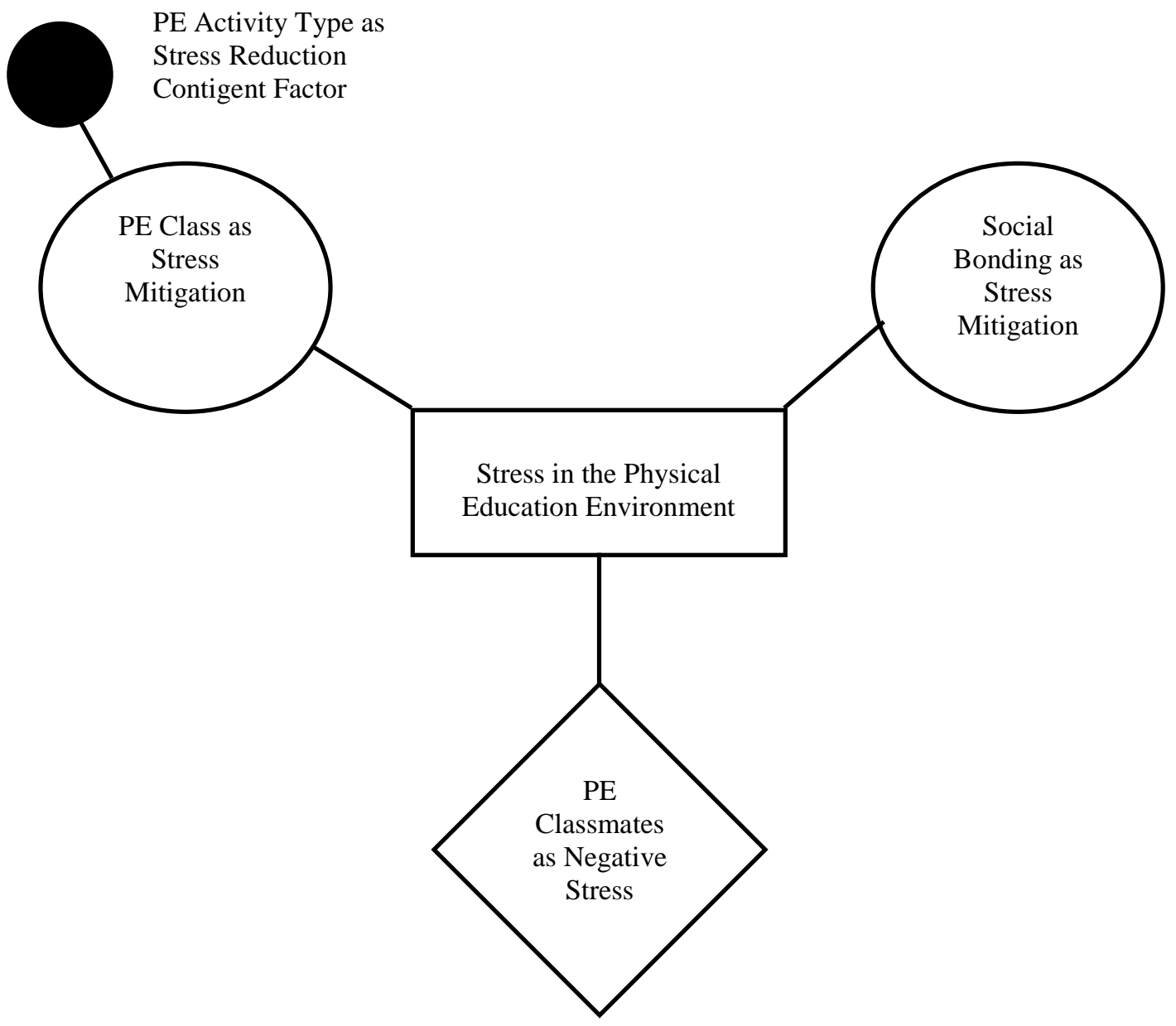

